\title{
SPORT IN TRANSITIONAL SOCIETIES - DISAPPEARANCE OF ROLE AND LOSS OF RESULTS
}

\author{
Miloš Šolaja ${ }^{1}$ \\ ${ }^{1}$ Faculty of Political Science, University of Banja Luka, Bosnia and Herzegovina
}

\section{SUMMARY}

Looking at the social transition as a complex network of social changes in all aspects of social life a comparison of changes in the field of sport in post-socialist societies in transition in relation to the developed system of sport on a global level, especially after the end of the Cold War and the major structural changes in early 90 s of the 20th century, comes as a necessity. If the transition in post-socialist societies is looked at as a need to depart from the collectivist values of the failed global project of socialism toward the direction of the values of liberal democracy, it becomes visible that the social subsystem of sport has remained untransformed and underdeveloped; an indicator of unsuccessfully implemented transformations and, at the same time, an obstacle to development. In most transition countries, which have not yet reached the social standards necessary for European integrations, the sport has not achieved the role it should have in the societies of liberal democracy and market economy either, despite the fact that it has become part of European and international policies in the field of sport. This paper should point at the framework of values within which the social subsystem of sport is coming into being in transitional post-socialist societies, at the relationship between the sport and the society, the value and economic role of sport in the political system, and, at the same time, explore why the sport is neglected in transition countries as an area to which international integrations spread out, i.e. the extent to which this is conflicting with the values that are in the origins of sports as well as the manner in which it is corresponding with those that transitional societies have opted for..

Key Words: consumerism, profit, sport, system, transformation, transition, values.

The first half of the current 2014 year was marked by the world football championship that many in the political and media sphere said was bigger in importance and in scope than the Olympic Games. This is a novelty that shows the significance of the economic side, commercialization and professionalization of sport. The Olympic Games, whatever the extent of their own commercialization and professionalization, remain in the shadow due to the de Coubertin's words "the important thing is to participate". The message is clear, to win at any cost becomes the unhidden imperative and the ultimate goal that is well paid. One part of this is the animation of audience, which can be seen from the editorial approaches taken by global news channels and networks, just like the local ones, which are demonstrating hunger for new types of TVs, organizational preparations for match watching and all other marketing-commercial. At the same time, the sport system of South-East Europe was surprised, or better to say amazed, by the case of the Belgrade-based Red Star Football Club that had been punished by the Union of European Football Associations (UEFA) over unpaid obligations towards its own players. The fact that this is a former European champion, a value category that is intensively used within the local frameworks in the attempts to achieve a higher socially and economically valorised position than the one earned on the basis of a recent real sport result, was of no help in terms of the UEFA's decision. ${ }^{1}$

${ }^{1}$ Old successes in international competitions are celebrated every year. The "Red Star" Football Club (Belgrade, Serbia) 
Both signals are largely clear. The first signal is that the world championship represents a step further in the consumerist and economic-marketing direction of further utilization of sport as a commodity-service with social consequences. The second signal is that we take the development of sport in the totality of social relations in transitional societies as incomplete and untransformed, and at the same time lacking value determination, a social sub-system as part of the overall social structure. We define it within the framework of differentiated political and economic changes that transitional societies embarked on after the caving in of socialism as one of the two global ideological concepts dominant until that time that was trying to resolve universal social concepts on the foundation of overcoming the class conflict, rather than the conflict between the states.

In keeping with such ideological, philosophical and political orientation, the system of sport was built on the inner values of "an exercise that develops mind and body" in the efforts aimed at developing a socialist man, which was radically changing the competitive philosophy that is imminent to sport as a human activity.

Sport is: the mechanism of expressing unity, [...] mechanism of absorbing and consuming of excess energy, [...] the way of harmless discharge of aggressive and accumulated energy... culture of the body [...] space in which human limitations disappear [...] a means for establishing human relations« (Kovačević, 2000, pp. 38-40).

The orientation of socialism towards sport relates, at the same time, to the general value perception of sport as "a profound interest in and engagement for other person's destiny, an athlete in that case" (Koković, 2000 , p. 163). By accepting the general human determination of sport, the socialist society commenced to develop this creation of the modern world, but shaping it in its own way in an attempt to use it for achieving its own values and social goals. This, of course, implies entirely new value foundations and elements - instead of a liberal competitive model that starts from the main principle that the sport result and its winner are a product of capitalist society and its values driven by the logic of capital and profit in marks intensively its winning of the Champions Cup (predecessor of the Europa League) in 1990, just like the "Borac" Handball Club (Republic of Srpska, Bosnia and Herzegovina) marks the winning of the Champions Cup in 1976. None of the two, and the same goes for many other clubs, have not still today reported a sport result that could measure up with the success from that time. sport as a "social industry", a concept of sport is created where sport is an opportunity for achieving a new man - an expression of the ideological aspiration about a society that will be contributed to according to the possibilities, and enjoyed in according to the needs. That way, the socialist society, in its initial form in the Soviet Union, took over the sport as a creation of the modern capitalist society attempting to adjust it to its own, exclusively ideological orientation and intrastate political pattern. The modern sport, reliant on the competitive pattern was created at the same place as the modern bourgeois state - in England and its global spreading started rather swiftly.

It is beyond any doubt that the English model of sport and its quick spreading were in the function of the pioneer experience and the pioneer role of England in the industrial capitalism. Moreover, at the time when England had already gone a long way into the second phase of industrialization, sometime up to 1880 , it was »at the peak of power (Skembler, 2007, p. 75).

The majority of sports were born in the AngloAmerican space forming, basically, the unchanging contents of Olympic Games up to date. As many as nine out of the eleven disciplines of the first sport competition between the Oxford and the Cambridge in 1864 today remain in the programme of the modern Olympic Games.

The social position of an athlete in socialism was, from the very beginning, marked by the position of the individual that belonged to the society - the socialist collectivity. The collectivity was materialised at more levels - starting from the school and the sport club up to the town or university levels, with the state being the highest one. In accordance with the Marxist definition of the class struggle, as a global social conflict implying the disappearance of the state, and in accordance with its foreign policy that believed from the time of its establishment that the global proletariat as a class was going to win and "eliminate" the state and relations of conflicts between the countries, the Soviet Union did not even imply the establishment of political relations with other countries. This automatically meant that it was not participating in sports competitions between the countries. Instead of achieving competition results as the underlying motive, good-quality world-class sport was exclusively placed in the role of the driver of sport-recreational massivity as the foundation and for serving the needs of the collective mass ideology. To that end, 
the socialist power, just like all other powers founded on totalitarism, organize so called "slets", as a supreme achievement of sports activity - massive sports manifestations as an absolute negation of competitiveness and results and that are emphasizing the meaninglessness of the individual in a collectivistly isolated society. In the political sense, the mobilisation of masses and the collectivisation of political activities represent the foundation of the political engagement of the bureaucratic layer that is departing more and more from the foundation it was born on. Such exaltation of the »bureaucratic layer«, a sort a special socialist bureaucratic social caste, separated from those that it declaratively pretends to be, is followed by the differentiated growth of a supreme sports bureaucracy, devoted to the party, that is developing in two directions: the first being the role of politicians as »benevolent « managers of sport associations and clubs; and with social ranking and a subsequent recognition of the sports result euphemised in various ideologically oriented recognitions such as "peoples' athlete", "meritorious athlete" and similar being the second one, by way of which the success in a sports competition receives definitively its material capitalization even though in a particularly euphemised way. It is, at the same time, both direct, material in apartments, material goods and money, and indirect as a reward in the social position.

The Socialist Bloc did not create proactively or in any different way its own sports disciplines as a competitive base in international relations, but copied entirely sports created in the lap of the modern capitalism. Copying related to the contents of a discipline and the essence of competition, form of training, but also to the position of an athlete and the valorisation of his results through the defining of the competition system and values. "Non-Western cultures get orientalistic self-comprehension that practically helps in beating the Western rationalism" (Giulianotti, 2008, p. 303). The socialist ideological collectivism was to be built as a sui generis sports system the goal of which was to demonstrate the supremacy over Western distorted conception of sport as a specific social commodity and mass consumerist goods euphoria. This would not have been possible if the sport in socialism had stayed locked inside its ideological armour and had not had to demonstrate its supremacy in relation to the other world. The concurrence of values of socialism in relation to liberal democracy is basically the first liberalist movement and the road taken by the process that is nowadays recognised as the transition of sport in transitional post-socialist societies. The road to it led across international competitions.
Contemplations on the matter started only at the time of the Nazi threat and after the Soviet Union's admission into the League of Nations in 1933. Stalin redefined, in those years, the class - Marxist international approach to the dictature of proletariat claiming that the building of socialism was possible in a single-isolated state, different from the West, which, at the time, could only relate to the Soviet Union as the sole socialist country. This definition opened up the way for the Soviet Union toward international competitions but it was not straight away that it joined the race. Its appearance on the international scene took place much later- its first participation in the Olympic Games was in 1952, in Tampere (Finland). The competitiveness i.e. the win as the objective of the entire process of sports preparations is thus, also, set up as a principle in political relations between countries. The new geo-political reality contributed to that, too - in the Eastern socialist bloc a number of countries emerged, formerly capitalist countries, transformed into socialist countries by the winds of the World War II under the auspices and the pressure of the Soviet military force and ideological coercion. Whatever the extent to which the sport movement, in its ideological-political base, in the old Soviet socialism, just like in the countries of the newly proclaimed popular democracy ${ }^{2}$ was, basically, built on non-state, non-political and non-profit foundations, that does not change the fact that it was created as the capitalisation of the sport result in the capitalist society bringing it into the position of use for the purposes of state policies and competitions between countries in international relations. The competition between countries meant a permanent confrontation of the two ideological projects, two geopolitical goals, two political and economic systems, two military blocs and conceptions and doctrines. What Marx called the social superstructure, i.e. what represented the sphere of culture as a form of hegemonic social structure, became part of competitions between global blocs of countries as a way to prove the prestige and gain strategic advantage within the framework of global

${ }^{2}$ The process of building of socialism under Stalin's ideological stick was not a smooth one. Being aware of the fact that the defeated countries of East and Central Europe cannot, over night, become members of the socialist community, Stalin defines "popular democracy" as a transitional form of capitalism of defeated capitalist cliques most of which collaborated with the Nazi Germany towards socialism. One-party power comprised of representatives of earlier communist parties, representatives of the resistance movement, countrymen that had fled to the Soviet Union just like ideological-political converts was the foundation. 
political confrontations. This sort of confrontation is transposed into the sphere of striving to achieve cultural hegemony, too, by way of which the sport, as a field characteristic for its simple measurability of success, becomes part of a global strategic rivalry between the big powers, but at the same time, of participation of small powers, small and other countries to show that they are present and are participating in world processes. Strong socialist countries used sport to realize themselves on the international scene. ${ }^{3}$

The act of competition in the international sports position represents the first act of liberalization on the global scene. While to win was not made into an imperative of the sport itself, i.e. it is the principle of participation that is set up, rather than that of the win, as the supreme ethical principle ${ }^{4}$, countries rather than athletes as individuals demand the win for the sake of their own ideological - political strategic goals. The win as a political imperative could not be achieved without personal ambitions of those participating in the sports process - whether it is the personal success of the athlete personally who is achieving this »high-level« state goal or the coach and sports official is irrelevant-both are individual acts of entrepreneurship and enterprise in a social sub-system, part of the social structure that is dekondira exactly the same efforts on the opposing political side - competitions correspond with each other making one of the global spheres in which one global social structure takes it shape, too. A germ of individualism is thus emerging within the state-political framework as the institutionalisation of ideological collectivism, as one of the fundamental values of liberal democracy. It can therefore be considered that transition in sport commenced the very moment when the countries founded on the ideology of socialism first appeared in the global competition arena.

The sport becomes individualised, and, just like trade and small services that no system has been, up to date, able to ideologise and place within the limits of the state-systemic collectivist discipline, ever since

\footnotetext{
${ }^{3}$ At the Olympic Games in Helsinki, the Soviet Union won no gold medal, but Emil Zatopek, a Czech(Slovak) was hailed as »the hero of socialism « who won two gold medals fin long-distance running. It is necessary to analyze successes achieved by Romania, Poland, Democratic Republic of Germany at a later stage all of which invested a lot in sports successes, especially in individual sports producing what were practically »sport machines« for winning, very often sticking at nothing.

${ }^{4}$ The first President of the International Olympic Committee, Pierre de Coubertin defines the sports ethic principle using the following words:«the important thing is to participate«.
}

the beginning of the human community and society as a whole, it defines itself as one of the elementary individual and social functions and appears as an individualization base that will later on be transposed into all social structure spheres as the base for caving in of socialism. Socialism and values of collectivism cease to represent a way of resolving social conflicts and liberal democracy remains a dominant form of democracy $^{5}$ and organization of societies founded on those values or craving for them. The issue that is inevitably raised is that of what the transition is just like the relationship between the process of changes to overall value foundations and the value structure of societies that have embarked on those changes and the sport as an inseparable segment of social structure in which a developed consumer society develops a series of needs that become the needs of the individual. The individualisation of the main players of sports competitions, individualisation of the audience and its consumerist needs close up the circle of necessary transformation of sport as a social sub-system, a fascination that reduced to the outer forms of the change. The outer "wall of changes" is, however, not sufficient for the sport to be generally transformed in the direction of genuine transitional changes of societies involved in the process, legging behind in the transition process in relation to the dynamics and the intensity of overall changes. This is, to a certain extent, exerting influence on the perception of postsocialist transition countries as insufficiently successful or completely unsuccessful. The sports reflexion of changes in those countries fits into the neoMarxist Wallerstein's definition of global interdependence according to which the world system consist of three types of countries:

- global centre - rich countries, dominant and with strong governments such as United States of America or European Union

- semi-periphery - societies that are trying to become financially stronger, the governments of which have modest possibilities and a limited technological development coming down to the development of consumerist goods such as East-Asian »tigers" or East-European nations

- periphery: countries with poor governments, contentious borders and structurally dependent on Western nations - African and Latin-American societies to a large extent (Baylis \& Smith, 2001, p. 207)

${ }^{5}$ The famous statement made by the British Prime Minister during the World War II who said that »liberal democracy is not perfect, but is the one of the best inventions the world has ever given us« 
The results of sport competitions after the end of the Cold War reflect precisely the Wallerstein's perception of global relations. The collective sports competitions in the "society-country-result" triangle give a more precise reflection of the picture. Countries and clubs celebrating old champion titles were unable to repeat the same successes after the Cold War and the beginning of global changes and it is already the early phases of competitions that, in most cases, represent an insurmountable result threshold. The countries falling under the category of periphery have been unable, in spite of painful and expensive efforts, to move away from that threshold, clubs and athletes from second-category countries - semi-periphery have sometimes reached the second phase, but not the very top. A different picture would not respond to the processes of transitional changes and would not give a proper answer in regard to the actual international position of societies and countries denominated as "new comers" in the global liberal community. After the fall of socialism, the centre-periphery processes, as defined by Wallerstein, appear to be even more visible in the sport. Transitional changes in what were formerly socialist communities reflect the transformation of entire communities in the direction of association with the international society that is characterised by the liberal democracy model. Changes were equally complex and deep and were geo-politically important not to represent, after the Cold War just like the post-socialist transitional changes, only internal issues of participating countries, but rather a common interest of the international community. This primarily goes for the correlation between the international context and liberal values that relate to the foreign concept of changes in all aspects (Šolaja, 2013). Changes animated all spheres of social life starting from the individual up to the entire population of post-socialist countries in East, Central and South-East Europe. Their main characteristic is the transitional shift from collective socialist values to the values of liberal democracy and designing of constitutions and political systems in accordance with that principal direction of development. The Western part of the international community was very much interested in steering those changes, while it was not entirely ready for the process at that point.

At the crucial moment of changes, neither Brussels nor Washington played a decisive role - Western "tailors" in general were overtaken by events they had not been able to foresee and could only watch from the sidelines" (Whitehead, 1994, p. 52).
And in spite of the relative lack of interest on the part of the Western centres of powers, societies that rejected communism and opted for Western values proclaimed momentaneous association with the European Union and close relations with the United States.

The admission into the circle of Western values was not an unconditional one. The European Union defined the conditions in 1993, known as the "Copenhagen Criteria", which implied key transformations towards efficient pluralist democracy, rule of law and protection of minorities and acceptance of behaviour in compliance with the principles of market economy. It was implied that a society that going through a transition in all of its aspects was going to launch its own transformations towards the fulfilment of given criteria, but the political elites and the leaderships in power obviously failed to understand this comprehensively. Political and economic transformations were on the top of the agenda, while other numerous segments of the social structure remained not only untransformed, but absolutely intact. The processes of changes did not spread onto the fields of social superstructure where the sport plays the lead role by its proportions and influence onto society. In transitional societies, it turns into "an unguided hand grenade", semi-socialist (semi-collectivist) hybrid, declaratively on individualist foundations, without succeeding in adjusting to post-modern processes. Essentially, efforts aimed at making "ethos" and "life styles" of new middle classes or "yuppies" into a dominant ideological cultural project within the framework of post-modern capitalism « (Jameson, 1991, pp. 406-407) were not successful. The sport management starts lacking sense and becomes disoriented, property is not defined but remains "generally-socially owned", but on undefined social goals. Such a structure is animating a relatively high asocial and socially vague conglomerate of managers, agents, sponsors, media magnates, sport media experts, lobbies and collective interests of athletes (syndicalisation). To win becomes the main objective in the function of individual, group, and, in the social-political sense, prevailingly local interest, whereby one sticks at nothing to achieve those goals. The new social elites, the designation of "new political class"could perhaps describe them in a more precise way, use sport to "The existence of the "club's assemblies" speaks about this that are elected on completely unclear bases and principles, practically in accordance with the principle that certain interest conglomerates, gathered around sport clubs legally registered as non-governmental organizations i.e. citizens associations, appoint themselves and then legalise, through the process of decision-making, their own interests. 
achieve one of their momentary interests. In most of the cases, it is the political need to achieve the momentary political interest, which is coming down to the elections and pressure on the opponent.

The sport structures that are most frequently used with such intentions are fans as a formally loosely uncontrolled, but sufficiently preserved populist element that could significantly contribute to the politically expected goal. By using, exclusively and solely, the "love for the Club" as the base for their organized, essentially diffuse and sometimes hard-tocontrol, political power in relation to sports organizations, such groups think they have the right to evaluate the Club's results, exert influence on appointment and dismissal of management. The influence of political and police structures on such an environment, essentially created on criminogenic social foundations, could not be realised if there were not corruption in the sport of transition countries as a means for achieving results, i.e. if sport results were not achieved through a combination of political-economic corrupt activities. The symbiosis of old-fashioned relations in the system of organization of sport and new value orientations of both athletes and political structures oriented to the political result had as a consequence this "colonization" of sport in which the big and the powerful buy the best of what is offered by the small in order to achieve their goals following the model of the sport product as a commodity. In the process, some local sport stars manage to become part of the international sports establishment, this world remains, however, unreachable and closed for local clubs and sports federations. Some semi-periphery countries, mainly newly admitted members of the EU, are in a colonial sport relationship in relation to the developed countries of the "centre", representing, at the same time, the targets of colonialised athletes from underdeveloped periphery countries. Value changes and the organization of sport in transition countries are unable to reach quickly the level established in the societies of developed capitalism. While a step forward towards the centre has been made in some Eastern countries, this process has not advanced a step further than the beginning in the Western Balkans area (a geographic area in South East Europe) as the last geographical enclave in the process of accession to the EU.

Sport clubs, as basic sports institutions have not been turned into organizations prepared to participate in international sports competitions and associations. Both legally and organizationally, they continue to exist as »nongovernmental organizations « or »citizens associations«, which is an archaic form of »social« or »state« economic ownership of sports organizations considered as an expression of "general-social interest". Even when the disappearance of socialism started to become clear, this abandoned noble and socially oriented objective formally and value-wise remains the main one. Changes, legal and formal, to the organizational form of socially-owned sports organizations have created a vacuum in the cementedness of old-fashioned forms of leadership and management (Šolaja, 2013, p. 77).

Formally weakened power of traditional social functions of the sport has set up "phantom owners" of sports institutions - that cannot be relied upon in the sense of ensuring the existence and functioning of sports organizations and that have not been feeling a great deal of obligation or need to finance, but have simply continued to indulge in the financial and political benefits.

A certain type of ownership over clubs and teams in the Western Balkans means, most of the time, the lack of official ownership over clubs, teams and it is called the exotic type of ownership, which, unconditionally, stands for an unidentified ownership, a confusing management system and an archaic system of competing (Grujić, 2013, p. 62).

The transition of values and the appearance of the "new class" have accelerated the attempts to include sport in global flows, but have, with their selfish approaches and narrow individual and group interests, failed to take a stance, in a good-quality and sufficient manner, on post-modernist processes in the development of culture (including the sport) at the end of the 20th century, because a principled engagement in global flows would not satisfy their functional conditions.

Global changes are related to the "postmodernist" or "chaotic" relations of production whose reflection in sport is reflected through economic division within national communities while the global system is dominated by the "transnational capitalist class" (Sklair, 1995, p. 61). Sklair names the class as "a type of an international management bourgeoisie". That class is composed of those who have global power in the interest alliance with the local partners. Those are the "politicians inspired by capitalism", sport professionals and groups of consumers whose main goal is to increase the mass purchasing power through "culture-ideology consumerism", creating the buying mood and the "consumerist worldview" that exceeds 
national boundaries. (Giulianotti, 2008, p. 294). This becomes a model to control international sport. Elite sport games and elite individual sports are in the control of international political and business elite, including media business and sports at the local level. Sport becomes the "fifth world industry", in its significance immediately after the oil, military, pharmaceutical industry or the industry of modern communication technology (Pavlovic, 2007). The industry of competition, marketing and advertising, the phenomena of the modern consumer society, the development of sport halls, betting shops, sports-information and marketing areas, became not only a huge part of modern life of an individual person, but one of the most important parts of the economy, therefore an important political issue. The "sport industry" is becoming influential in modern global politics.

New political elites as a product of the collapse of socialism, many of which resulted within it, proclaimed the capitalistic model of sport as a consumerist-oriented product, without understanding or initiating changes at the national level at the same time. While striving to become a part of the postmodern global establishment in the global international sphere, in the internal, national or interstate sphere, they remained the traditional sport autocrats who respected sport as a mean of achieving present political or potentially financial interests. While the liberalization of sport is internationally recognized as a principle and an aspiring system of values, at the local level, it remains non transformed sphere of society in political, economic and, generally, structural view. From this dichotomy of values arises the need to transform the sport, which in the direction of active participation in the international sport system is even prevented ${ }^{7}$. In most of the transitional countries, as well as in the greater parts of non developed world, abandoning the old concept disturbs the global commodity-economic positioning of sport. "Neoliberal policies devastated the infrastructure of the developing countries" (Giulianotti, 2008, p. 293).

\footnotetext{
${ }^{7}$ An attempt to make a "brand" of the Handball club "Borac" (the Republic of Srpska, Bosnia and Herzegovina), which almost in any occasion emphasizes its two international champion titles, through the selling of copy-jerseys, scarves, hats or subscription for seats, organization of the schools of handball and building of sport hall, failed. Conservative forces were directed to financing from the previous "safe" funds - the general sponsor which was not very interested in the result and the public budget. That was a way to keep the club under control of political-economic interest groups, who were not very interested in the liberal approach to sport, and to enrich the sport management in a corrupt way.
}

At the time of the system values when the sport success was not necessarily valorised from the consumer-political point of view, there was a part of a secret that some societies at the time could participate in the division of sport results and success which is shown in the given examples of European and world titles. The design and functionality of sport equipment (jerseys, balls, sports requisites, sport halls, fixed grounds, etc.) changed slowly. The market's role of sport within the paradigm frameworks of cultural consumerism was not primary, though in time it became stronger. The post-modernism brings divisions, the classic "working class" is gone, and the middle economic layer enters the global scene, which is a more numerous "new class" in various forms of management, engineering, mediation, sale of services, sale of existentially unnecessary consumer goods. This layer accepts, and also encourages, the consumer culture to enjoy the dazzling consumerism.

In the era of liberal capitalism, the most recent age of development in the West, which started in the early seventies of the last century that we usually called the age of early or disorganized capitalism, was a witness to changes in the sport that occurred at the same pace as the changes in society (Scembler, 2007, p. 284).

Some of the culturally identified consumerist values are the relics and the sport is a leader of it. Sport clubs start often to change the design of the equipment and the accompanying marketing, and the greatest value in the product is "branding" of the club's name or an individual, in other words, the creation of new identities based on the "faith" in consumerist sport stars whose marketing messages start to be used in nationwide dimensions.

It is through this kind of sport audience that the capacity of the receiver of (media) messages is growing. Not only that it receives the messages, but it identifies itself with them and it becomes an unavoidable part of sport events [...] it becomes a part of interpersonal communication, the thinking and most importantly, the result and business communication as well (Šolaja, 2001, p. 210).

It is characteristic of the transitional societies that the messages are not local or national, but international and global. Sports become television and media events ${ }^{8}$ and they change in the direction of modern ${ }^{8}$ The Olympic games in Atlanta in 1996 are said to be the first Olympic games, because the basis of its financing made the rights of TV broadcasting, advertising industry and marketing. 
social subsystem as a significant global framework of overall social changes through global processes in the terms of business. Including the commercialization of information and the industry of communication, the industry of sport equipment and sport processes are becoming a part of business philosophy and economic liberal society as goods that are valorised in the market.

"The sports are becoming television events, not real events" (Baudrillard, 1993, pp. 79-80). The international sport is subordinated to television and the advertising industry. Not only the time of competition, but the way of presenting the events is subordinated to "its highness" the television and the thing it brings with it - the advertising industry. The result and the accompanying atmosphere on the field are transient, an indirect aim, while the commercial industry and profit making are dominant. The audience and the viewers become a direct object of television attention and an inseparable part of an event. The real sport disappears, changed by the way of television presentation about it, which affects the way of participation of athletes and the huge television audio visorium as actors of a sport event. Culture differences are more reduced, and sports are becoming global. Sport federations are less related to the sport as confederate national associations, and they are becoming more the business associations endeavouring to "increase the value of their goods in the market, and the media are directed by the right political elite with the minimal transparency" (Hoberman, 1995, p. 36). The sport associations are gradually becoming multinational corporations that in the recent years may be recognized by the global scale corruption. Unlike the 'traditional' sport corruption - bribery of judges and fixing the results in order to artificially win, the corruption is transferred to the international relations so that even the procedure of deciding about the place of the Olympics or world championships are the subjects of corruption. Everything becomes global media and cultural event, as well as global corruption.

Today sport is more and more left to the media. The media is the best example of how to politicize the sport, to spread and devour the domains of everyday human life which is apparently free and neutral (Koković, 2004, p. 45).

The participation of transitional countries in the global media sport-show remains insignificant and concealed. The countries that are struggling to reach the level of political and economic standard and are still investing a lot of efforts in that direction, have had no economic opportunity, nor strength to develop a consistent concept and strategy of sport development. Even the main areas did not change quickly, so the sport remained at the margins of the process. In the initial phase the changes took place in the spheres of politics and economics and in the efforts to bring the rule of law which was set a priority task of the "international community" or the 'western mediators' of the transitional process. It is obvious that the process, being too much under the influence of the necessity of changes, required a stronger and more consistent participation of the western countries.

An element of the democratization process certainly had an important international component as well. Even though the bottom intensifies the pressure or it emphasises strategic importance of the political elite, the national and international components of the process were so intertwined that it would be impossible to separate them artificially (Whitehead, 1994, p. 57).

The transition from the authoritarian government goes to the "consolidation of liberal democracy", acting on several fronts, and at the same time leading to the consolidation of democracy and the market economy. The post-authoritarian regimes remain more or less indeterminable due to the introduction and development of new values. The sport is not placed in the first line of leading policies which, being unchangeable, could present a paradigm and one of the pillars for the recovery of certain forms and foundations of authoritarian governance within the transitional changes. This is particularly related to the transitional changes in the South-eastern Europe where it was defined the "failure of international policies towards the former Yugoslavia, which in a great way overshadows the whole transitional process." (Ibid, p. 52).

The democratization of Albania and the former Yugoslavia was the least liberal in the Eastern Europe, because it became a tool of extremely intolerant nationalists. The liberal democracy was built in a much greater extent and more rapidly than in the countries of East and Central Europe (Poland, the Czech Republic, Slovakia and Hungary), but with the changeable stability. Somewhere between those two examples, there is the democratization that took place in Romania and Bulgaria (Herring, 1994, p. 88). 
In this phase of transition, there are specific symbiosis of the liberal values and the sustainability of liberal democracy, market economy and the rule of law and the remaining socialist values in the form of an interest-group organizing formalized in the political parties as organizational form, corrupt and uncompetitive economy and completely irresponsible legal systems which are not able to secure the rule of law not even in one single area of life, including the sport that, on the contrary, becomes the space lacking the complete legal or social norms, as well.

In the transitional societies, it is not only about the lack of legal regulation and legal behaviour, it is more the problematic values of the vacuum in the period between leaving the socialism and accepting the liberal values that destructively affected the development of sport as a socially responsible business. The changes in international sport were not sufficient motive or goal of the political elite in order to direct the development in that direction. In essence, they did not want that either, in the way that most of them do not want the membership of their countries in the European Union or other international associations. The containment of sport is suitable to block the formally proclaimed goals. Their political relation towards the sport is maintained at the level of 'local' spectacle - using the sport success or a scandal in daily political needs expressed in an electoral campaign, political disputes or arguments. Unclear status of ownership where a club becomes a "social good", but functioning in favour of the private economic and political interests, the highest range of sport organizations becomes para-state organization of clubs and, possibly, the support to national representations whose limited international success is more directed to the internal political needs than to a real positioning at the international sport scene. Copying the "Soviet state model" in the transitional conditions is shortlived and does not occur as a result of the systematic creation of "state teams", but is more a compilation created by purchasing of individual sport success of earlier produced "local stars" with a very limited result goals - to the level of identification of the audience with the local political elite.

This sort of para-state organization of sport institutions clearly limits and spoils the fundamental elements of sport as a social sub-system, in the first place its property, and after that the other spheres like training, preparations, financing, management, education and media coverage (Šolaja, 2013, p. 77).
Sport competitions in the transition countries ${ }^{9}$, especially those created from the previous multinational federations represent unsuccessful copies of earlier competitive systems, but at a much lower basis of mobilization of athletes, organizations, ethic relation, and ultimately of economic position. Therefore, in the terms of media, they remain uninteresting, and the audience is focused towards the international media that create the appearance of active participation in huge and mass sport events.

The sport and the projection of future is left to those who are involved in sport, most of which did not go in the direction of strategic thinking, but were in the field of individual benefit, usually achieved in a way of corruption. By focusing on the transitional social changes in the South-eastern Europe, the political elite of the six countries of the Western Balkans, Romania and Bulgaria as well, neglected the area of sport that in the most economic potentials participates in the culture sphere and failed to position the sport as an important part of large efforts to achieve the goals in the direction of European Integrations. The failure of inclusion in commercial-cultural consumerist sphere, prevents the active relation towards the changes and continues the inertia of the earlier system in which the legal base of ownership, property and financial operations remained trapped in the "nongovernmental sector" and they function according to legal regulations for civil society, although the goals are absolutely profitable. The management remains formally general-social, but it is essentially established on the basis of the private arrangement. The successful part of the inclusion in the international sport is entirely individual ${ }^{10}$ and it is mostly represented by the athletes who their knowledge and skills in sport are trying to sell themselves as profitable goods. The most commercially profitable sports in the transitional countries are absolutely non-profitable because ${ }^{9}$ The countries of Eastern and Central Europe have gone through the huge geopolitical changes after the Cold War. The Soviet Union was divided in 15 new countries, the disintegration of Yugoslavia brought six new countries. In both cases the disintegration of multinational federations produced new 'sub-states' as well that tend to get the status of the state. With the peaceful dissolution of Czechoslovakia, the total number of countries that include themselves in the area of Europe increased from 35 to 47, which is the present number of the member states of the European Council.

${ }^{10}$ This may explain the "phenomenon Djoković" - the management of his success is not "state", which is not desirable, but it is not the product of regulating the social ambience for the sport development, as well. It is solely the result of individual efforts of a competition and a "family business" to achieve the result. 
there are no great investments by the businesses, nor the investments in their media presentation. Tycoons are much less present in the sport than the local politicians who are very interested in the points and the prestige that the sport is bringing to them. The representatives of the businesses make investments mostly when some of the politicians express their need with the intention to achieve some other benefit. The principle is known as the "racket", a specific form of corruption, because it is conditioned by it.

The consequence of the lack of clear perception about the role of sport in the postmodern international relations and the lack of vision and strategy of development in their valuable environment is an insufficient organizational and financial transformation in a way to correspond with the international sport system and to participate in the division of international sport and economic results, unidentified transformation of ownership, which provides a certain circle of individuals to irresponsibly manage in order to achieve the individual benefit, most often through corruption and other economic forms of management, media maintenance of sport at the local boundaries or outside the participation in the system of international media ${ }^{11}$ and social changes in general. Public policies in sport do not integrate in the overall integration public policies making them thus absolutely underdeveloped. The political elite of the transitional society does not show the interest in sport. In great part, declaratively pro changes, the vast majority participate in the transformation of sport as a sub-system on the basis of economic or political corruption which enables them to establish the consequent system of values appropriate to the direction, dynamic and the intensity of changes. One of the suitable directions for the determination of values is the participation of sport in peace in the development of peace (General Assembliy Resolution of United Nations, 1994) as a general human value, although at the moment it seems that the key decision-makers in sport would preferably join to the sport concept of class and goods as a predominant one in global scale with the regard to the incompleteness and the lack of the sport development strategy. For the ruling elite, that is much closer and easier than to develop the approaches and activities that could bring the sport back to the original humanistic and universally human values of humanity, generosity, peace building and cooperation between the states in an effort to make

\footnotetext{
${ }^{11}$ In the post-Yugoslavian area, it is very often the case not to present the results of top sport competitions in the countries - previous republics of the same country.
}

the liberal international environment more flexible to meet the needs of people.

\section{REFERENCES}

Baudrillard, J. (1993). The transparency of evil. London, Great Britain: Verso.

Baylis, J., \& Smith, S. (2001). The globalization of world politics. New York, NY: Oxford University Press.

Grujić, M. (2013). Organization, financing and ownership of sports clubs in the stock market. In S. Simovic and V. Stankovic (Eds.), 4th International Scientific Conference "Anthropological aspects of sports, physical education and recreation" (pp. 5264). Banja Luka, Bosnia and Hezgeovina: Faculty of Physical Education and Sport. doi: 10.5550/SP.4.2012.06

Giulianotti, R. (2008). Sport-kriticka sociologija [Sport - critical sociology]. Belgrade, Serbia: CLIO.

Herring, E. (1994). International security and democratisation in Eastern Europe. New York, NY: St. Martin s Press.

Hoberman, J. (1995). Toward a theory of olimpic internationalism. Journal of Sport History, 22(1), $1-37$.

Jameson, F. (1991). Postmodernism or the cultural logic of late capitalism. London, Great Britain: Verso

Koković, D. (2000). Sociologija sporta [Sociology of sport]. Belgrade, Serbia: Sportska akademija.

Koković, D. (2004). Sport i mediji [Sports and media]. Novi Sad, Serbia: Fakultet za uslužni biznis

Kovačević, B. (2000). Sociologija sporta [Sociology of sport]. Banja Luka, Bosnia and Herzegovina: Centar za stručno obrazovanje i usavršavanje trenera - Centar za sport.

Pavlović, R. (2007, September 3). Peta svetska privredna grana [The fifth global industry]. Politika online. Retrived from: http://www.politika.rs / rubrike/Sport/30098.sr.html

Skembler, G. (2007). Sport i drustvo [Sport and society]. Belgrade, Serbia: CLIO.

Sklair, L. (1995). Sociology of the global system. Baltimore, MD: John Hopkins Universitz Press Šolaja, M. (2001). Globalizacija, saveremeni mediji i savremeni sport. Defendologija, 4(10), 205-214.

Šolaja, M. (2013). Sport in a neo-liberal post-socialistinternational context. In S. Simovic and V. Stankovic (Eds.), 4th International Scientific Conference "Anthropological aspects of sports, physical education and recreation" (pp. 72-82). Banja Luka, Bo- 
snia and Hezgeovina: Faculty of Physical Education and Sport. doi: 10.5550/SP.4.2012.08 General Assembliy Resolution of United Nations. (1994). Sport for development i peace. No. 19431. Retrived from http://www.un.org/wcm/con- tent/site/sport/home/resourcecenter/resolutions/ pid/19431.

Whitehead, L. (1994). East-Central Europe in comparative perspective. New York, NY: St. Martin's Press.

Received: Jun 10, 2014

Revision received: Jun 30, 2014

Accepted: Jun 30, 2014

Correspondence to: Miliš Šolaja, PhD

Faculty of Political Science Bulevar V. Petra Bojovića 1A 78000 Banja Luka

Bosni and Herzegovina Phone: 0038765515112

E-mail:msolaja@teol.net 